\title{
CLUSTERING OF MILLENNIALS BY BRAND PERCEPTIONS IN RELATION TO DEMOGRAPHIC FACTORS
}

\author{
Braciníková, V., Matušínská, K.
}

Veronika Braciníková, Kateřina Matušínská / Silesian University in Opava, School of Business Administration in Karvina, Department of Business Economics and Management, Univerzitní náměstí 1934/3, 73340 Karviná, Czech Republic.Email: bracinikova@opf.slu.cz, matusinska@opf.slu.cz.

\section{Abstract}

The corporate brand represents a global set of perceptions of the unique functional and emotional attributes associated with it. These are the result of interactions of all the impressions, experiences, feelings and knowledge of all participating sides based on the products of the company, management style, and the planned or unscheduled communication activities. The study aims to describe Czech Millennials using demographic criteria in relation to their brand perception. The questionnaire was used as the research technique for gaining the primary data. The respondents were questioned about their opinions and perceptions of many issues such as attitudes towards brands, life values, willing to pay, making decisions, searching and buying products, preferences in the field of stability, having fun. Several statements from the questionnaire were tested for the purpose of this paper connected to the sense and sensibility in the decision buying process of Millennials as the consumers in the marketplace of the Czech Republic as one of the Central European countries. Afterwards, the Millennials are classed according to these pre-selected variables into groups by using a cluster analysis in such a way as to ensure the greatest similarity within the clusters and the greatest variation between clusters. Two clusters were formulated. From the carried out survey is obvious consumers with a lower degree of education are more emotional when they purchase goods than consumers with other achieved degrees of education. In relation to gender, we can allege that women are much more motivated by emotions. Younger Millennials are more likely to be motivated by emotions than older ones. Implications for Central European audience: Businesses in the $21^{\text {st }}$ century, especially in developed markets should focus on the adequate targeting of selected market segments to use adequate marketing programs because the use of mass marketing approaches in different areas of business is currently uncompetitive and sometimes totally impossible. Proper targeting has a significant impact on consumers' behaviour and their brand perceptions. The Central European countries such as Poland, the Czech Republic, Hungary, Liechtenstein, Germany, Switzerland, Slovakia, Slovenia and Austria, with a population exceeding 165 million, represent a solid and an attractive market for business opportunities. Ordun (2015) claims that customers (consumers) of so-called generation $Y$ (also said as Millennials) are said to be the second-largest population all of the world. It represents an occasion as well as a challenge not only for business units. Individuals of this generation have very strong buying power but they can as well influence the buying decisions of their parents and children. Moreno, Lafuente and Moreno (2017) present the findings of their research that suggest that Millennials were born in the time period when the technology is understood as an important part of people's life in all aspects. Thanks to this fact Millennials 
perceive buying process as joy and their loyalty to purchased brands is relative. They are supposed to spend the money which they earn quickly using the online shopping channels.

The current research projects in the area of the currently ongoing and still unfinished phenomenon of the generation $Y$ within the Central European countries does not bring clear and comprehensive results with the possibility of their reliable application on a practical level. The aim of this article is, therefore, to describe Czech Millennials using demographic criteria in relation to their brand perception. The results of the presented marketing research can be understood in general terms as applicable to other Central European countries which are supported by research conducted by Motyka (2017, p. 178) who states that "Czech Millennials are similar to their peers in other European states, but of course not identical because they usually differ from their European peers in terms of life priorities: enrichment and chasing certain trends are not as important for them."

Keywords: brand perceptions; generation; Millennials

JEL Classification: M10, M30

\section{Introduction}

In respect to the development of modern marketing, when marketing communication has become one of the main ways of achieving corporate goals, it is necessary to identify the opportunities for increasing its impact on consumer behaviour. To communicate on the market properly and to enhance marketing communication effect, it is essential to deliver relevant news and content to the target audience. As a consequence of this, the first step of every successful company should be knowing of its customers.

As one of the keys to the success of companies, it is possible to mark customer orientation, it means to look at everything from the perspective of customers. Therefore, it is necessary to consider what customers want and need. At the same time, to define how they make their buying decisions, how they meet their needs and, based on this knowledge, to generate the right way of communication. The concept of modern marketing is based on the necessity to have and manage such knowledge.

It is apparent that the survival and growth of business entities in today's economic system depend largely on the acquisition and existence of accurate and detailed information about buyers. Companies should understand on what, why, where and when consumers choose to spend their money. There are many impulses on the market, which influence the perceptions of the consumers and consequently their decisions. These impacts result in certain patterns of consumer behaviour. It is necessary to obtain information related to this behaviour for better comprehending of consumers. Such information is understood as information about customer needs, attitudes, personal reactions, deeds or decisions, which can be based on emotional or rational fundamentals. Therefore, this study focuses on consumers' perceptions identifying their preferences when shopping, having fun in life or adapting to changes.

Because the emotional face of the personality is always superior to the rational one, it is imperative to evoke positive emotions in the consumers. The company can make it through communication and building a strong brand. The brands and communication are the links 
between the company and the customers because the company distinguishes one brand from another by communication. The corporate brand represents a global set of perceptions of the unique functional and emotional attributes associated with it. These are the result of interactions of all the impressions, experiences, feelings and knowledge of all participating sides based on the products of the company, management style, or the planned or unscheduled communication activities. That is why this study, among other issues, deals with the attitudes of consumers towards brands. Therefore, this study aims to describe Czech Millennials using demographic criteria in relation to their brand perception. An earlier version of this paper has been presented at the International Conference on Decision making for Small and Medium-Sized Enterprises (DEMSME, 2019).

\section{Literature review}

While the basic principle of previous corporate communication was to convince consumers, conversation and interaction is the basic principle of present and future corporate communication. This means that the development and maintenance of interactive communication and the relationship with an individual consumer becomes a decisive factor.

Also, according to Reicher and Szeghegyi (2015), operative strategies and marketing concepts have changed fundamentally. If the product is not a centre of marketing anymore, the goal is not to sell a particular product in any quantity to anyone with the maximum profit, but the consumer gets into the marketing viewfinder. The common goal of marketers, retailers, and businesses is to sell all sorts of goods and services to consumers with the highest possible profit and satisfaction of customer needs.

Kotler and Armstrong (2010) argue that the general process of developing and maintaining useful communication with the customers is to deliver value to the customers and to reach their satisfaction. The role of communication in a company's business activities can be seen from different perspectives because companies do not only create brand awareness among customers but also use it as a tool for building a strong image for these brands. Kim and Chao (2020) suggest based on their research project that both consumers' rational perceptions and emotional feelings play a crucial role in the process of a brand building among consumers. The relationship between brand image and brand trust, which is the initial stage in the brand building process, plays a crucial role in consumers' purchasing decisions. It is also very substantial to take into account the different ways in the brand building process for high and low engagement product categories.

According to Mitra and Jenamani (2020) the image of a brand is understood in the minds of consumers due to the kindness, strength and uniqueness of brand associations. Gaustad, Samuelsen, Warlop and Fitzsimons (2019) propose a theory of consumer response to changes that dampen or expand the associations that are central to brand image (due to brand acquisitions or repositioning). Current research examines the potential disadvantage of building brand associations that resonate with consumer identities and facilitate the interconnection of consumer brands. The results of their study show that consumers with a high degree of connection to their own brand react more negatively than others to changes that are dampened by brand associations. Conversely, changes in expanding brand associations may in some cases lead to unfavorable consumer sentiment. When branding was associated with an ideal identity (motives for self-improvement), changes that broadened the brand's image increased the brand's ability to signal an ideal identity. Conversely, when 
the merger of the brand was associated with a real identity (motives of self-control), the expansion of the brand image reduced the perceived similarity between self and the brand, which caused a deterioration in the identification of the brand. Klein et al. (2019) examine the influence of the country's image on the brand image and state that age, education, being female, and the need for structure increase the fit effect of $\mathrm{BICl}$ (brand image-country image), while materialism reduces it. In addition, $\mathrm{BICl}$ fit is more concerned with categories that are closely linked to the local cultural context or that are described by high purchasing risk. Furthemore, Pratminingsih, Astuty and Mardiansyah (2019) reveal in their study that a brand image has a mild impact on the relationship between electronic word of mouth (eWOM) and purchasing decisions.

Sellers are not only able to produce products or provide services. The primary importance of the future accomplishment of business objectives in the marketplace is communication. It follows, of course, that it is important for retailers to get current and potential customers familiar with their brand. Additionally, it is equally very important to make sure that customers keep thinking about it (Okyere, Agyapong, \& Nyarka, 2011). Customer loyalty to the brand is a complex concept that includes a cognitive, emotional and behavioural dimension. Most customer loyalty surveys focus on conditions (based on relative levels of loyalty, attitudes, and behaviour) or loyalty formation phases (Dapena-Baron, Gruen, \& Guo, 2020). Bloemer and Kasper (1995) argue that in defining the concept of brand loyalty, a distinction differences must be taken into account between customers' repeated buying behaviour and brand loyalty. Repeated buying behaviour is a genuine brand renewal. What matters is only the re-purchase behaviour, regardless of the degree of consumer engagement with the brand. However, brand loyalty does not only mean re-purchase behaviour, but also takes into account the actual predecessors of behaviour. Therefore, they identify two different types of brand loyalty: true brand loyalty and false brand loyalty. In an appropriate manner, true brand loyalty is considered as biased, as the behavioural response, which is expressed over time and made by some decision-making unit. And this all with respect to alternative brands which represent the function of psychological processes the result of which is brand commitment, whereas the false brand loyalty is a function of inertia (Bloemer \& Kasper, 1995).

Research has shown that brand confidence is rooted in past brand experience and is also positively linked to brand loyalty, which in turn maintains a positive relationship with brand assets (Delgado-Ballester, \& Luis Munuera-Alemán, 2005). Brand loyalty has very close relation to brand equity. According to Aaker (1991), the equity of a brand is a collection of brand assets and liabilities associated with the brand, its name and symbol, which increase or subtract the value provided by the product or service to the firm and its customers. To support brand equity, assets or liabilities must be associated with the brand name and/or symbol. If the brand name or symbol were changed, some or all of the liability assets could be affected and even lost, although some could be moved to the new name and symbol. Aaker (1991) also ads that the liabilities and assets of brand equity can be divided into five categories like brand loyalty, brand awareness, quality perceived by consumers, brand association and other proprietary brand assets. Foroudi et al. (2018) report that marketing activities can create perceptional and behavioural mechanisms of brand equity. Scientists are aware of a number of factors that create the perceptional mechanisms of brand equity. Nevertheless, all concur that a common factor in achieving positive brand perception is the marketing communication plan. It has been stated that high brand perception is the result of effective marketing strategies and that marketers are responsible for building brand 
dimensionality. Marketers also contribute to building brands' opinions and principles, thus generating positive relations in consumers' minds and creating a positive approach concerning the brand. According to Iglesias et al. (2019) the brands have to face with increasing pressure to integrate ethical values into their identities and to show their ethical commitment at the corporate level. Ethics perceived by the customer have a significant and indirect impact on brand equity through mediators of brand recognition benefits and image. In addition, the brand heritage negatively affects the influence of the ethics perceived by the customer on the brand image. Managers must be aware of the need to strengthen the brand image and the benefits of recognition, as this can facilitate the translation of customerperceived ethics into brand equity.

The processes of consumer behaviour are affected by marketing communications created and based on the outputs of research and segmentation in the area of marketing. Hun and Yazdanifard (2014) define segmentation as the gradual distribution of individual customers to larger groups based on specific features such as age, gender, interest and habits. This allows allocating marketing resources efficiently to these specific customer groups.

Every consumer is an individual with specific characteristics, but there are some attributes according to which the consumers can be clustered. The most common are the demographic factors, which can have or not a significant influence on the selected issues. That is why it is important to investigate these possible relations to segment the market. Kotler and Armstrong (2018) declare that demographic segmentation of the market is organized according to variables like age, gender, income, occupation or education. The procedure of demographic variables use is the most widespread in the process of segmentation. In the first place, the reason is that consumers' needs, wishes and consumption proportions often vary narrowly with demographic variables. In the second place, demographic variables are easier to quantity than most other types of variables and usually, they are the first base for the use of other segmentation variables as geographic, behavioural and psychographic.

Companies frequently practise marketing segmentation in marketing communications, including advertising aimed at specific consumers. Hun and Yazdanifard (2014) consider segmentation according to generations as primary because it provides many benefits, of course in the case that the research is properly realized and then thoroughly implemented.

The knowledge and forecasts regarding the customers are useable in a certain period. Therefore, it is required to track customer moves between segments to observe changes in segments over time, and then explore segment knowledge and foretell customer segment behaviour patterns. Aggregation of each customer's pathway reveals the dominant pathways that most customers follow. It is thinkable to calculate the next path that each customer is likely to move by examining dominant paths. This is useful in answering correctly to customers and implementing customer-centered strategies (Sung, 2007).

Generations are characterized by age, period and cohort. Whereas the age represents era at which life events or transitions of singulars take place. The period means happenings within lifetime of an individual. A cohort denotes a group of people who have shared similar event and experiences during their formative years and these shared experiences could lead to similar attitudes and positions for the rest of their lives (DeVaney, 2015). Many definitions of generations can be found in the literature. Builders were born between 1920 and 1945, Baby Boomers between 1946 and 1964 (Ordun, 2015). The members of generation $X$ were born 
between 1965 and 1979, generation $Y$ between 1980 and 1997, and generation $Z$ grows (Solomon, 1992; Weingarten, 2009; Hauw, \& Vos, 2010; Hole, 2010; Ordun, 2015). Deal, Altman and Rogelberg (2010) claim that generation Y, also called Net generation (Shaw, \& Fairhurst, 2008), Next generation (Martin, 2005) and the most used Millennials, is different from previous generations.

Millennials are tough customers who suppose greater selectivity, personalization and customization of their products and services. The precise years of birth of Millennials vary a little depending on demographers. Prensky (2011) states that Millennials are determined as "digital natives". In contrast, "digital immigrants" are people who arrived online after having a substantial life offline. According to Prensky, baby boomers and even some members of Generation X are digital immigrants. Hyllegard, Yan, Ogle and Attmann (2011) explain that the difference between Millennials and previous generations is related to the shifts of values on the side of Millennials generation. Millennials have been influenced by a different set of societal, cultural and economic events that have affected them, including the immersion of communication technologies into everyday life (Wong et al., 2008). Howe and Strauss (2003) claim that individuals of this segment have usually grown in a safe and target-oriented environment. Aggarwal and lacobucci (2004) announce that they have a small number of siblings and therefore the home competitive atmosphere is moderate. According to Borges et al. (2006) this generation likes working in a team, in an organized and integrated culture (Jerrard, 2002) and growth-oriented culture (Eisner, 2005; Viswanathan, \& Jain, 2013). Berkowitz and Schewe (2011) add that Millennials believe that teamwork will support them to realise their aims with no troubles than individual work. However, they want to achieve their goals in a short period of time and they are available for constant feedback. Millennials are generally against reading and they consider text-based reports ordinary. They read news and text on digital media, and they select opulent graphic data than simple text communications (Carr, \& Ly, 2009).

Millennials desire distinctive signs with their own characters that will use as a way of individualism (Gupta, Brantley, \& Vanessa, 2010). This generation is compared to the other generations characterized more cluttered, materialistic and their consumer culture is primarily considered as the result of technological innovation (Hanzaee, \& Aghasibeig, 2010). Some scholars claim that the Millennials are like they want everything and they want it now in context of rewards and quick progress, work-life balance, or attractive work and contribution to society (Ng, Schweitzer, \& Lyons, 2010).

According to several authors (Cui, Trent, \& Sullivan, 2003; Valentine, \& Powers, 2013), the Millennials represent a strong aggregate demand. Given that Millennials are three times larger than generation $\mathrm{X}$, they symbolise the major segment of market from the generation Baby Boomers (Belleau et al., 2007; Ordun, 2015). Given the value of Millennials for sellers, it is significant to recognise the behaviours of this age group (Swinarski, Parente, \& Noce, 2010). It is relevant because of the reason that Millennials are despite similarity in the size of their parents Baby Boomers, almost in everything else very different (Ciminillo, 2005). Thus, defining the exact stimuli that influences Millennials, their approaches and shopping behaviour has become an essential emphasis of end users investigation (Martin, \& Bush, 2000).

That is why this study aims to describe Czech Millennials using demographic criteria in relation to their brand perception. The intention was to find out what the millennials think 
about influences in their decisions making, as well as whether there is a brand on the market that they might say they love it, what is quite a strong statement. From this point of view, the following research question was formulated: How do the chosen demographic factors influence the sense and sensibility in the decision buying process of Millennials?

\section{Materials and Methodology}

To reach the aim of this study, the questionnaire as the research technique for gaining primary data was used. The survey took place in November 2017. The questionnaire was distributed by the research agency IPSOS to a research sample. A total of 1050 of respondents completed the questionnaire. Although, two respondents were excluded due to incorrect completion of the questionnaire. Finally, the research sample consists of 1048 respondents. The survey was focused on the generation of Millennials, that is why the respondents were consumers of this segment.

All of the collected data were categorical. Some of the data were nominal like gender (dichotomous), occupation (polytomous), and other data were ordinal like age category, education and also the level of agreement with statements. By the statements the respondents were questioned about their opinions and perceptions of many issues as attitudes towards brands, life values, willing to pay, making decisions, searching and buying products, preferences in the field of stability, having fun. They were inquired to express their level of agreement with the statements on the scale of 1 (absolutely agree), 2 (agree), 3 (rather agree), 4 (neither agree nor disagree), 5 (rather disagree), 6 (disagree) and 7 (absolutely disagree). For this study, specific statements were chosen to answer the research question.

\subsection{Sample characteristics}

The research was focused on the generation of Millennials in the marketplace of the Czech Republic. From that it follows that the respondents had to meet the requirement about the age; it means they had to be born between 1980-1997. There were not any other limitations regarding the demographic factors. A sample of respondents was composed based on demographic factors as follows. According to gender, there were $51 \%$ of male and $49 \%$ of female. According to age, the respondents were divided into three groups. The respondents in the age from 20 to 25 years old (26.9\%) represented the first group. The respondents aged 26-31 were the second group with $31.1 \%$. The last and the largest group was composed of the respondents between 32 to 37 years old with the representation of $42 \%$. According to the achieved level of education, the respondents were divided into four groups. The respondents with primary school (6.3\%) represented the smallest group. $25.8 \%$ of respondents obtained a degree at a vocational school. The largest group representing $46.5 \%$ was composed of respondents with a high school degree. $21.4 \%$ of respondents achieved the university level of education. According to the occupation, there were eight possible options, the respondents could choose from. Finally, the structure of the respondents was $14.1 \%$ of students, $45.6 \%$ of employees without subordinates, $9.3 \%$ of line managers (1-5 subordinates), $5.1 \%$ of senior managers (6 and more subordinates), $4.1 \%$ of entrepreneurs, $16.5 \%$ of people in the household on parental leave, $4.2 \%$ of involuntarily unemployed and $1.1 \%$ of voluntarily unemployed. For better orientation the research sample according to presented demographic factors is shown in Table 1. 
Table 1 | The composition of respondents according to chosen demographic factors

\begin{tabular}{|c|c|c|c|c|c|c|c|}
\hline \multicolumn{2}{|c|}{ Gender } & \multicolumn{2}{|c|}{ Age } & \multicolumn{2}{|c|}{ Education } & \multicolumn{2}{|c|}{ Occupation } \\
\hline Male & $51 \%$ & $20-25$ & $26.90 \%$ & $\begin{array}{l}\text { Primary } \\
\text { school }\end{array}$ & $6.30 \%$ & Student & $14.10 \%$ \\
\hline \multirow[t]{7}{*}{ Female } & $49 \%$ & $26-31$ & $31.10 \%$ & $\begin{array}{l}\text { Vocational } \\
\text { school }\end{array}$ & $25.80 \%$ & $\begin{array}{l}\text { Employee } \\
\text { without } \\
\text { subordinates }\end{array}$ & $45.60 \%$ \\
\hline & & $32-37$ & $42.00 \%$ & High school & $46.50 \%$ & $\begin{array}{l}\text { Employee - } \\
\text { line manager }\end{array}$ & $9.30 \%$ \\
\hline & & & & University & $21.40 \%$ & $\begin{array}{l}\text { Employee - } \\
\text { senior manager }\end{array}$ & $5.10 \%$ \\
\hline & & & & & & Entrepreneur & $4.10 \%$ \\
\hline & & & & & & $\begin{array}{c}\text { In the } \\
\text { household, on } \\
\text { parental leave }\end{array}$ & $16.50 \%$ \\
\hline & & & & & & $\begin{array}{l}\text { Involuntarily } \\
\text { unemployed }\end{array}$ & $4.20 \%$ \\
\hline & & & & & & $\begin{array}{l}\text { Voluntarily } \\
\text { unemployed }\end{array}$ & $1.10 \%$ \\
\hline
\end{tabular}

Source: own research

\subsection{Methods}

Several statements from the questionnaire were tested for this paper connected to the sense and sensibility in the decision buying process of Millennials as the consumers in the marketplace of Central Europe, specifically the Czech Republic. The data was tested by SPSS software. IBM SPSS Statistics is one of the world's leading statistical systems for applications in science, marketing, human resources and research, for processing laboratory measurements and for summarizing data from large and smaller databases of various types. It is used for financial analysis, decision-making modelling and time series analysis and prediction. Its versatility ensures coverage of needs in different parts of the organization, thus ensuring compatibility and simplifying the preparation of management and management materials.

We used the chi-square test for finding relations among the statements and demographic factors. The chi-square test aims at comparing the actual frequencies within each category of a nominal variable against its expected frequency. The six steps of the chi-square test procedure were implemented (Israel, 2008): (1) Null and alternative hypotheses formulation. The null hypothesis is that there is no difference in the proportion of respondents in the different categories of the variable while the alternative hypothesis has the opposite meaning. (2) Data converting into a tabular form. (3) The expected frequencies for each of the categories finding out. (4) Chi-square value finding out by applying the formula. (5) The critical chi-square value finding out for 0.05 level of significance. (6) The decision making by comparing the calculated and critical chi-square value.

Afterwards, we tried to perform, which factors had a significant influence on the tested statements. In the next step, we used the cluster analysis, which classes statistical units according to pre-selected variables into (groups) clusters in such a way as to ensure the 
greatest similarity within the clusters and the greatest variation between clusters. The most common use is found for segmenting the customers. Cluster analysis methods are divided into two basic groups: non-hierarchical cluster methods and hierarchical cluster methods (Rimarčík, 2007). Hierarchical cluster methods are designed to detect embedded clusters within multidimensional data. Coupling begins with linking the individual observations closest to each other in the space defined by the variables used in the analysis. Once these clusters are formed, they are combined with other clusters or individual observations to form larger clusters. This process continues until all observations are combined into one cluster.

Due to the nature of the data, we have decided to apply the hierarchical cluster method, namely Ward's method. This method seeks to create stable and approximately identical groups. It is a clustering technique that is not based on minimizing the gap between clusters (like other, most commonly used hierarchical cluster analysis methods), but on optimizing cluster homogeneity.

\section{Results}

As already mentioned in the previous text, some statements were investigated for the purpose of the study. The Millennials should have expressed the degree of consensus with them. The statements concerned various areas. There was the area including the sense in the process of making decisions, preferring stability, sensibility in a relation to enjoying the fun and trying new things, attitudes toward the brands and willingness to pay more money for quality. These statements were tested relating to four demographic factors as follows gender, age, education and occupation. The demographic factors are independent variables and the statements represent dependent ones. The relations between these variables were investigated. Subsequently, the null $(\mathrm{H} 0)$ or alternative $(\mathrm{H} 1)$ hypotheses were accepted or rejected. While the null hypothesis declares the absence of the relations between the tested variables, the alternative one declares the existence of relations between the investigated variables. The results are shown in Table 2 and Table 3, where the numbers of statements are as follows: (1) "I make all the decisions after careful consideration of possible variants, I do not deal with emotions." (2) "In life I prefer stability, no big changes." (3) "I like trying new things." (4) "It is important for me to enjoy as much fun as possible in my life." (5) "There is a brand on the market I love." (6) "I'm trying to find all available information about my favourite brand." (7) "I follow fan pages of my favourite brands." (8) "I always search for products of my brand online." (9) "I always buy products of my brand online." (10) "I only want the best and I'm willing to pay for it." Data met general requirements for using chi-square test. Expected frequencies for each cell were at least 1. Expected frequencies for the majority $(80 \%)$ of the cells were at least 5 . We tested two categorical variables, which are not paired in any way. According to the results of Pearson Chi-Square test is also determined the $p$ value (Asymp. Sig.) and degree of freedom. Table 2 shows results of investigating gender and age, Table 3 shows the results from testing level of education and occupation. 
Table 2 | The relations between chosen demografic factors (gender, age) and the statements

\begin{tabular}{ccccccccccc}
\hline & \multicolumn{1}{c}{ Gender } & \multicolumn{9}{c}{ Age } \\
\hline $\begin{array}{c}\text { No. of } \\
\text { statements }\end{array}$ & H0 & H1 & $\begin{array}{c}\text { Pearson } \\
\text { Chi- } \\
\text { Square }\end{array}$ & df & $\begin{array}{c}\text { Asymp. } \\
\text { Sig. }\end{array}$ & H0 & H1 & $\begin{array}{c}\text { Pearson } \\
\text { Chi- } \\
\text { Square }\end{array}$ & df & $\begin{array}{c}\text { Asymp. } \\
\text { Sig. }\end{array}$ \\
\hline 1. & $\times$ & $\checkmark$ & 18.906 & 6 & $\mathbf{0 . 0 0 4}$ & $\checkmark$ & $\times$ & 9.000 & 12 & 0.703 \\
2. & $\checkmark$ & $\times$ & 12.325 & 6 & 0.055 & $\times$ & $\checkmark$ & 23.229 & 12 & $\mathbf{0 . 0 2 6}$ \\
3. & $\checkmark$ & $\times$ & 4.629 & 6 & 0.592 & $\checkmark$ & $\times$ & 16.458 & 12 & 0.171 \\
4. & $\checkmark$ & $\times$ & 3.713 & 6 & 0.716 & $\times$ & $\checkmark$ & 32.067 & 12 & $\mathbf{0 . 0 0 1}$ \\
$\mathbf{5 .}$ & $\times$ & $\checkmark$ & 26.354 & 6 & $\mathbf{0 . 0 0 0}$ & $\checkmark$ & $\times$ & 18.441 & 12 & 0.103 \\
$\mathbf{6 .}$ & $\times$ & $\checkmark$ & 38.038 & 6 & $\mathbf{0 . 0 0 0}$ & $\checkmark$ & $\times$ & 9.899 & 12 & 0.625 \\
7. & $\checkmark$ & $\times$ & 11.222 & 6 & 0.082 & $\times$ & $\checkmark$ & 26.312 & 12 & $\mathbf{0 . 0 1 0}$ \\
$\mathbf{8 .}$ & $\times$ & $\checkmark$ & 14.796 & 6 & $\mathbf{0 . 0 2 2}$ & $\times$ & $\checkmark$ & 23.665 & 12 & $\mathbf{0 . 0 2 3}$ \\
$\mathbf{9 .}$ & $\times$ & $\checkmark$ & 22.029 & 6 & $\mathbf{0 . 0 0 1}$ & $\checkmark$ & $\times$ & 15.533 & 12 & 0.214 \\
$\mathbf{1 0 .}$ & $\times$ & $\checkmark$ & 15.328 & 6 & $\mathbf{0 . 0 1 8}$ & $\times$ & $\checkmark$ & 30.663 & 12 & $\mathbf{0 . 0 0 2}$ \\
\hline
\end{tabular}

Source: own research

As we can see from Table 2 many relations were found out. The relation from detected relations connected to gender was found in the case of the statement "There is a brand on the market I love." The men, surprisingly, answered more positively than the women. They chose the option "absolutely agree" more frequently $(9.72 \%$ of $51 \%)$ than the women $(6.97 \%$ of $49 \%)$. And the women chose the option "absolutely disagree" more often $(4.01 \%$ of $49 \%)$. Another relation was found in the context of the statement "I'm trying to find all available information about my favourite brand." Also, in this case, the men chose the positive options more often than women, which is also quite surprising, but according to previous findings equally obvious. The relation was found also in the case of the statement "I always buy products of my brand online." The same situation as two previous. The men answered more positively. The relation was found in the case of the statement "I make all the decisions after careful consideration of possible variants, I do not deal with emotions." We found out that the men chose the option "agree" more frequently $(14.4 \%$ of $51 \%$ than the women $(10.22 \%$ of $49 \%)$. And the women, on the other hand, chose the option "rather disagree" more frequently $(6.21 \%$ of $49 \%)$ than men $(3.43 \%$ from $51 \%)$. Thus, we can say that men behave more rationally when buying products. Another relation was found with the statement "I only want the best and I'm willing to pay for it." The men are those who are willing to pay for the best on the market compared to women. The last relation was found in the statement "I always search for products of my brand online." The men were more likely to search for and buy a product online than women. The relation in the cases of other statements was not found.

The respondents were divided into three groups according to the demographic factor age. The first group consists of respondents aged 20-25, which means that the respondents can be still the students. The second group are the respondents in the age between 26-31. And the last group is represented by the consumers aged 32-37 years. Also based on this factor the respondents were tested. From 10 investigated statements, in the 5 cases, the relations were found. The relation was found in the statement "It is important for me to enjoy as much fun as possible in my life." The first group chose the strongest option "absolutely agree" the 
most $(6.49 \%$ of $26.9 \%)$. The second relation was found in the case of the statement "I only want the best and I'm willing to pay for it." The first group is more willing to pay for the best on the market than the other groups. It is quite interesting that respondents do not closely follow the fan pages of their brands, despite the relation in the case of the statement "I follow fan pages of my favourite brands" was found. The respondents from the third group chose the most negative answer "absolutely disagree" the most often and with clear lead $(8.59 \%$ of $42 \%)$. Another relation was found in the statement "I always search for products of my brand online." The respondents from the first group are used to searching for products online more than other groups. The last relation was found in the case of "In life, I prefer stability, no big changes." It is quite expected that the third group answered the most frequently in a positive way than the other groups.

Table 3 | The relations between chosen demografic factors (education, occupation) and the statements

\begin{tabular}{cccccccccccc}
\hline \multicolumn{1}{c}{} & \multicolumn{1}{c}{ Education } \\
\hline $\begin{array}{c}\text { No. of } \\
\text { statements }\end{array}$ & H0 & H1 & $\begin{array}{c}\text { Pearson } \\
\text { Chi- } \\
\text { Square }\end{array}$ & df & $\begin{array}{c}\text { Asymp. } \\
\text { Sig. }\end{array}$ & H0 & H1 & $\begin{array}{c}\text { Pearson } \\
\text { Chi- } \\
\text { Square }\end{array}$ & df & $\begin{array}{c}\text { Asymp. } \\
\text { Sig. }\end{array}$ \\
\hline 1. & $\times$ & $\checkmark$ & 30.662 & 18 & $\mathbf{0 . 0 3 1}$ & $\checkmark$ & $\times$ & 51.610 & 42 & 0.147 \\
2. & $\checkmark$ & $\times$ & 25.550 & 18 & 0.111 & $\checkmark$ & $\times$ & 57.332 & 42 & 0.058 \\
3. & $\times$ & $\checkmark$ & 31.116 & 18 & $\mathbf{0 . 0 2 8}$ & $\times$ & $\checkmark$ & 71.993 & 42 & $\mathbf{0 . 0 0 3}$ \\
4. & $\times$ & $\checkmark$ & 38.233 & 18 & $\mathbf{0 . 0 0 4}$ & $\checkmark$ & $\times$ & 43.538 & 42 & 0.406 \\
5. & $\times$ & $\checkmark$ & 48.084 & 18 & $\mathbf{0 . 0 0 0}$ & $\checkmark$ & $\times$ & 56.644 & 42 & 0.065 \\
6. & $\times$ & $\checkmark$ & 45.141 & 18 & $\mathbf{0 . 0 0 0}$ & $\times$ & $\checkmark$ & 59.382 & 42 & $\mathbf{0 . 0 4 0}$ \\
7. & $\times$ & $\checkmark$ & 33.995 & 18 & $\mathbf{0 . 0 1 3}$ & $\checkmark$ & $\times$ & 49.738 & 42 & 0.192 \\
8. & $\times$ & $\checkmark$ & 44.739 & 18 & $\mathbf{0 . 0 0 0}$ & $\checkmark$ & $\times$ & 56.383 & 42 & 0.068 \\
9. & $\times$ & $\checkmark$ & 34.405 & 18 & $\mathbf{0 . 0 1 1}$ & $\times$ & $\checkmark$ & 59.005 & 42 & $\mathbf{0 . 0 4 3}$ \\
10. & $\times$ & $\checkmark$ & 32.097 & 18 & $\mathbf{0 . 0 2 1}$ & $\times$ & $\checkmark$ & 64.218 & 42 & $\mathbf{0 . 0 1 5}$ \\
\hline
\end{tabular}

Source: own research

Most relations were found in the factor of education. Just between the statement "In life, I prefer stability, no big changes" the relation was not found and it means that we accept the null hypothesis: Degree of education has no significant influence on preferring stability before changes in the life. The relation was found between all other statements and the factor of education. It means that we have to reject all the null hypothesises and accept all the alternative ones. The relation was found in the case of the statement "There is a brand on the market I love", where the greatest differences in answers were seen between the vocational degree of education and the university degree. The respondents with the vocational school were more identifiable with the highest levels of agreement with the statement $(4.78 \%$ of $25.8 \%$ of respondents with the vocational school chose the option "absolutely agree"). Another relation was found in the cases of statements "I'm trying to find all available information about my favourite brand" and "I always search for products of my brand online", the differences were caused by similar reasons.

Just four relations were found in the case of occupation, as the demographic factor. The relation was found in the case of the statement "I like trying new things". The students and entrepreneurs were the only ones, who answered the option "absolutely disagree". Within the other groups, this option was not chosen at all. "I only want the best and I'm willing to pay for 
it" was another statement, in which the relation was found. The senior managers did not choose the option "absolutely disagree" and "disagree" at all. The relation was found also in the case of the statement "I'm trying to find all available information about my favourite brand". The entrepreneurs and the students most likely answered it in a negative way than the other groups. The last relation was found in the case of the statement "I always buy products of my brand online". The line managers, the senior managers, the entrepreneurs are used to buying products of their brand online more frequently than the other groups.

Afterwards, cluster analysis was conducted. All of the variables, which were used in testing by chi-square test are also used in cluster analysis. We just wanted to summarize the answers of the respondents and create segments with possibilities to become loyal ones. Based on investigated determinants two segments of Millennials were created (Table 4).

Table 4 | Created clusters of Millennials according to investigated determinants

\begin{tabular}{|c|c|c|}
\hline Variable & Cluster 1 & Cluster 2 \\
\hline Gender & Male & Female \\
\hline Age & $32-37$ & $26-31$ \\
\hline Education & High School & High school \\
\hline Labour & $\begin{array}{l}\text { Employee without } \\
\text { subordinates }\end{array}$ & $\begin{array}{l}\text { Employee without } \\
\text { subordinates }\end{array}$ \\
\hline $\begin{array}{l}\text { Careful consideration of possible variants in decision } \\
\text { making process. }\end{array}$ & Rather agree & Rather agree \\
\hline Preferring of stability, no big changes. & Rather agree & Rather agree \\
\hline Liking to try new things. & Rather agree & $\begin{array}{l}\text { Neither agree nor } \\
\quad \text { disagree }\end{array}$ \\
\hline Enjoying as much fun as possible. & Rather agree & $\begin{array}{l}\text { Neither agree nor } \\
\quad \text { disagree }\end{array}$ \\
\hline Loving a brand. & Rather agree & Rather agree \\
\hline $\begin{array}{l}\text { Searching of all available information about favourite } \\
\text { brand. }\end{array}$ & Rather agree & $\begin{array}{l}\text { Neither agree nor } \\
\text { disagree }\end{array}$ \\
\hline Following fan pages of favourite brands. & $\begin{array}{l}\text { Neither agree nor } \\
\text { disagree }\end{array}$ & $\begin{array}{l}\text { Neither agree nor } \\
\text { disagree }\end{array}$ \\
\hline I always search for products of my brand online. & Rather agree & Rather agree \\
\hline I always buy products of my brand online. & Rather agree & Rather agree \\
\hline I only want the best and I'm willing to pay for it. & Rather agree & Rather agree \\
\hline Absolute (relative) number of observations & 404 (38.5\%) & $644(61.5 \%)$ \\
\hline
\end{tabular}

Source: own research

As we can see from Table 4 the first cluster is formed predominantly by male gender aged 32 to 37 years. These respondents have obtained a high school degree and they work as the employees without subordinates. Within this cluster, the most responsive answer for the statements was "rather agree", except the statement "I follow fan pages of favourite brands". The respondents belonging to this cluster have predispositions to become loyal to the brand. They like stability, fun and also trying new things. They carefully consider the options, but when they decide for some, they can even love the chosen variant (brand). These respondents search for and buy the products of their favourite brand online. They like 
searching for all available information about them. And the important finding is that they want the best and they are willing to pay for it. According to answers to given statements, we can allege that the ratio of sense and sensibility of respondents belonging to cluster 1 is balanced.

The second cluster is composed mostly of female gender aged 26-31 years. Also, in this cluster, the degree of achieved education is high school and the respondents work as the employees without subordinates. The respondents of cluster 2 chose the answer "neither agree nor disagree" four times more than the cluster 1. This option was chosen as the response to have a liking for trying new things or enjoying as much fun as possible in life. From these data two variants of situations are possible. The first one is that the respondents from this cluster use more sense than sensibility in the decision buying process. The second one is according to available resources more possible. The women are just more indecisive when they purchase. However, in the case of statement related to loving some brand on the marketplace, the respondents from this cluster answered "rather agree". From this point of view, we can say that when the brand (company) communicates with customers in the right way, they can fall in love with it. Afterwards, it can cause a decrease in the level of indecision. Searching for all available information was also marked by a neutral answer "neither agree nor disagree". The same answer was the most used also for following fan pages of favourite brands. Based on these findings the company knows that it has to reach the customers by a different channel than by its fan page and generate rather remarkable content than informative.

The results of the cluster analysis are also demonstrated, just for the illustration, in Figure 1 in the form of Dendrogram, which is arranged in a tree structure. The dendrogram represents a diagram showing clusters of respondents (in our research) according to the strength of correlation of compounds.

Figure 1 | Dendrogram

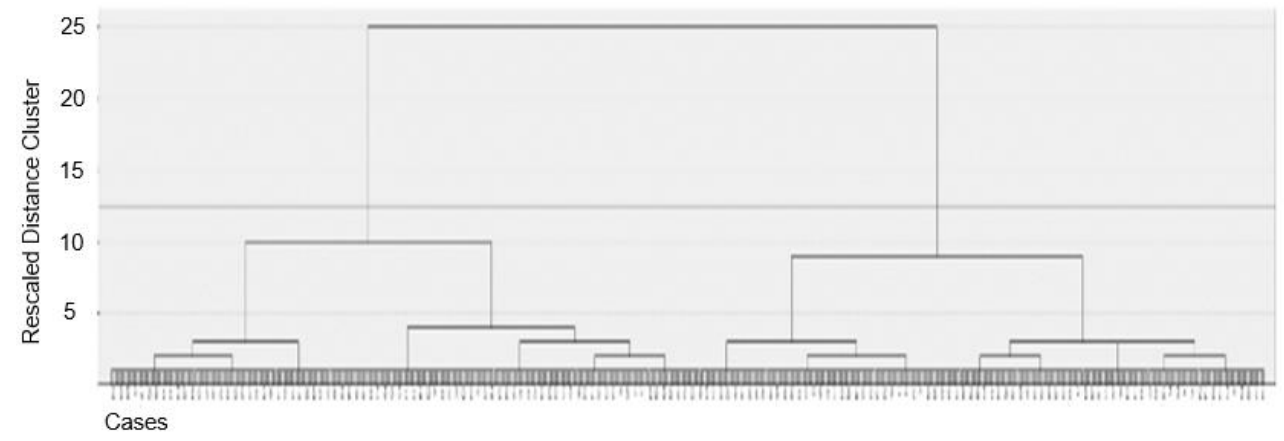

Source: own research

\section{Discussion}

The study is designed for the managers of companies operating in Central Europe. The results of the study can help these companies better understand the behaviour of very perspective segments of customers, Millennials. There are not so many studies focused on the investigating of Millennials in the conditions of the Czech Republic, that is why the necessity of the research on this field of study lasts. 
According to Klapilová Krbová (2016), Millennials perceive shopping as a necessity for life rather than a pleasure and fun. At the same time, they prefer well-known stores, both online and offline. Individuals of this generation do not have problems with online shopping, they consider it faster than shopping in brick-and-mortar stores, especially men. In-store sales promotion activities are especially appreciated by women, who acknowledge the impact of special offers and discounts on their purchasing decisions.

There are some other studies aimed to the field of Millennials connected to the brand perceptions (Velčovská \& Hadro, 2016; Braciníková \& Matušínská, 2020), work values (Ď́sek \& Suchanec, 2018). However, these studies are primarily focusing on describing Millennials as the generation. Like Taylor (2018) declares clustering customers just based on the generation affiliation is not enough anymore and researchers have to consider the differences among the consumers inside of one generation, too. Thus, the studies focusing on clustering the consumers within the generation are required.

The study brings insight to the differences within the consumers of Millennial generation. The limitations of the study could be seen at the way of data collecting because the online panel contains just the consumers, who are using the internet. However, IPSOS agency is a certified company in the field of quality assurance of collected data.

The results of the modified research could be used in further research to classify preferences towards specific product categories. In future research, attention could also be focused on identifying psychographic and behavioural indicators determining differences among the Millennials.

\section{Conclusions}

Choosing the right means of communication, of course, is not just about getting detailed customer data, but it is necessary to continue processing with this information. Afterwards, based on this information it is possible to segment the market and to distinguish among different groups of consumers. There are several generations of consumers on the market, Baby Boomers, Generation X, Millennials or Generation Z. These generations have been exposed to a variety of historical events during their lives, and therefore they have different needs of purchasing products and also their communicational and content requirements are different.

As it was already mentioned every consumer disposes of individual characteristics, however, they can be also clustered according to concrete attributes, which they have in common. For clustering the demographic factors are used the most with a prediction that some of them have and some of them do not have a significant influence on the chosen issues. That is why it is important to investigate and to confirm or reject these possible relations for the purpose of segmenting the market.

The study focused on the segment of Millennials. This segment is very much discussed in the literature, but not fully understood. That is why the surveys in the field of Millennials are required. It is needed to investigate their opinions, attitudes, perceptions, models of behaviour as the consumers in the marketplace. Thus, we focused on finding out the ratio between the sense and sensibility in the decision buying process. 
From the carried-out survey, we can state that the consumers with a vocational degree of education are more emotional when they purchase than consumers with other achieved degrees of education. Consumers who achieved a university level of education are motivated also by the emotions, however, before that they carefully consider the options. It means that at first, the brand has to reach their high requirements in the field of communication, quality, value, content and afterwards it can get loyal customers. In relation to gender, we can allege that men can become loyal consumers of brands more likely than women. It is more difficult to reach men than women, but when it happens, they become and stay loyal. The women more often tend to switch the brands. It means that they are much more motivated by emotions. Younger consumers from our segment of Millennials are more likely to be motivated by emotions than older ones and they are willing to pay for the best products in the marketplace. The consumers in management positions are more likely willing to pay for the best products than other employees, which is quite expected.

Today's consumers are looking for pleasure, positive emotions, fun, stability, fast service, a perfect sales process, and the uniqueness of the offer to suit their needs. It is just up to the companies how forcefully they can adapt themselves to these circumstances.

The companies can use the findings in the process of building adequate marketing communication to the generation of Millennials because the study focuses on this segment. Millennials are very much discussed in the literature, but not fully understood. That is why the surveys in the field of Millennials are required. It is needed to investigate their opinions, attitudes, perceptions, models of behaviour as the consumers in the marketplace. Thus, in this study, we focus on finding out the ratio between the sense and sensibility in the decision buying process.

\section{Acknowledgement}

This research was financially supported by the Student grant competition project SGS/7/2017: "Acceptance of technology from the perspective of marketing tools".

\section{References}

Aaker, D.A. (1991). Managing brand equity. New York, NY: The Free Press.

Aggarwal, P., \& lacobucci, D. (2004). The effects of brand relationship norms on consumer attitudes and behavior. Journal of Consumer Research, 31(1), 87-101. https://doi.org/10.1086/383426

Belleau, B.D., Summers, T.A., Xu, Y., \& Pinel, R. (2007). Theory of reasoned action purchase intention of young consumers. Clothing and Textiles Research Journal, 25(3), 244-257. https://doi.org/10.1177/0887302X07302768

Berkowittz, N.E., \& Schewe, D.S. (2011). Generational cohorts hold the key to understanding patients and healthcare providers: Coming-of-age experiences influence health care behaviors for a $\begin{array}{llll}\text { lifetime. Health } \quad \text { Marketing 190-204. } & \text { 28(2), }\end{array}$ https://doi.org/10.1080/07359683.2011.572029

Bloemer, J.M., \& Kasper, H.D.P. (1995). The complex relationship between consumer satisfaction and brand loyalty. Journal of Economic Psychology, 16(2), 311-329. https://doi.org/10.1016/01674870(95)00007-B 
Borges, N.J., Manuel, R., Elam, C., \& Jones, B. (2006). Comparing Millennial and Generation X medical students at one medical school. Academic Medicine, 81(6), 571-576. https://doi.org/10.1097/01.ACM.0000225222.38078.47

Braciníková, V., \& Matušínská, K. (2020). Brand meaning for consumers from dissimilar generations. Scientific Papers of the University of Pardubice, Series D, 28(1), 29-42.

Carr, A., \& Ly, P. (2009). More than words: Screencasting as a reference tool. Reference Services Review, 37(4), 408-420. https://doi.org/10.1108/00907320911007010

Ciminillo, J.A. (2005). Elusive Generation Y demands edgier marketing. Automotive News, 79, 28.

Cui, Y., Trent, E.S., Sullivan, P.M., \& Matiru, G.N. (2003). Cause-related marketing: How Generation Y responds. International Journal of Retail \& Distribution Management, 31(6/7), 310-320. https://doi.org/10.1108/09590550310476012

Dapena-Baron, M., Gruen, T.W., \& Guo, L. (2020). Heart, head, and hand: A tripartite conceptualization, operationalization, and examination of brand loyalty. Journal of Brand Management, 27(3), 355375. https://doi.org/10.1057/s41262-019-00185-3

Deal, J.J., Altman, D.G., \& Rogelberg, S.G. (2010). Millennials at work: What we know and what we need to do (if anything). Journal of Business and Psychology, 25(2), 191-199. https://doi.org/10.1007/s10869-010-9177-2

Delgado-Ballester, E., \& Munuera-Alemán, J. (2005). Does brand trust matter to brand equity? Journal of Product \& Brand Management, 14(3), 187-196. https://doi.org/10.1108/10610420510601058

DeVaney, S.A. (2015). Understanding the Millennial Generation. Journal of Financial Service professionals, 69(6), 11-14.

Ďásek, K., \& Suchanec, M. (2018). Generational differences in work values - Impression or reality? The case of Czech Generations X and Y. Economics Management Innovation, 10(2), 36-52.

Eisner, S.P. (2005). Managing generation Y. Advanced Management Journal, 70(4), 4-15.

Foroudi, P., Zhongqi, J., Suraksha, G., Foroudi, M.M., \& Kitchen, P.J. (2018). Perceptional components of brand equity: Configuring the symmetrical and asymmetrical paths to brand loyalty and brand purchase intention. Journal of Business Research, 89, 462-474. https://doi.org/10.1016/j.jbusres.2018.01.031

Gaustad, T., Samuelsen, B.M., Warlop, L., \& Fitzsimons, G.J. (2019). Too much of a good thing? Consumer response to strategic changes in brand image. International Journal of Research in Marketing, 36(2), 264-280. https://doi.org/10.1016/j.jiresmar.2019.01.001

Gupta, M., Brantley, A., \& Vanessa P.J. (2010). Product involvement as a predictor of Generation Y consumer decision making styles. The Business Review, 14(2), 28-33.

Hanzaee, K.H., \& Aghasibeig, S. (2010). Iranian Generation Y female market segmentation. Journal of Islamic Marketing, 1(2), 165-176. https://doi.org/10.1108/17590831011055897

Hauw, S.D., \& Vos, A.D. (2010). Millennials' career perspective and psychological contract expectations: Does the recession lead to lowered expectations? Journal of Business and Psychology, 25(2), 293-302. https://doi.org/10.1007/s10869-010-9162-9

Hole, D. (2010). Talking about whose generation? Why western generational models can't account for a global workforce. Deloitte Review, 18(6), 84-97.

Howe, N., \& Strauss, W. (2007). Millennials go to college (2nd ed.). Chicago, IL: Paramount Market Pub. 
Hun, T.K., \& Yazdanifard, R. (2014). The impact of proper marketing communication channels on consumer's behavior and segmentation consumers. Asian Journal of Business and Management, 2(2), 155-159. https://doi.org/10.24203/AJBM.V2I2.1219

Hyllegard, K.H., Yan, R., Ogle, J.P., \& Attmann, J. (2011). The influence of gender, social cause, charitable support, and message appeal on Gen Y's responses to cause-related marketing. $\begin{array}{llll}\text { Journal of Marketing } & \text { 100-123. }\end{array}$ https://doi.org/10.1080/02672571003683755

Iglesias, O., Markovic, S., Singh, J.J., \& Sierra, V. (2019). Do customer perceptions of corporate services brand ethicality improve brand equity? Considering the roles of brand heritage, brand image, and recognition benefits. Journal of Business Ethics, 154(2), 441-459. https://doi.org/10.1007/s10551-017-3455-0

Israel, D. (2008). Data analysis in business research: A step-by-step nonparametric approach. New Delhi: Sage publications India.

Jerrard, J. (2002). Bridging the gap: Four steps to engage members of every generation in your workplace. EMS Manager \& Supervision, 4(9), 1-2.

Kim, R.B., \& Chao, Y. (2019). Effects of brand experience, brand image and brand trust on brand building process: The case of Chinese Millennial generation consumers. Journal of International Studies, 12(3), 9-21. https://doi.org/10.14254/2071- 8330.2019/12-3/1

Klapilová Krbová, P. (2016). Generation Y attitudes towards shopping: A comparison of the Czech Republic and Slovakia. Journal of Competitiveness, 8(1), 38-54. https://doi.org/10.7441/joc.2016.01.03

Klein, K., Völckner, F., Bruno, H.A., Sattler, H., \& Bruno, P. (2019). Brand positioning based on brand image-country image fit. Marketing Science, 38(3), 516-538. https://doi.org/10.1287/mksc.2019.1151

Kotler, P., \& Armstrong, G. (2010). Principles of marketing (13th ed.). New Jersey: Prentice-Hall.

Kotler, P., \& Armstrong, G. (2018). Principles of marketing (17th ed.). Harlow, UK: Pearson Education Limited.

Martin, C.A. (2005). From high maintenance to high productivity: What managers need to know about Generation Y. Industrial and Commercial Training, 37(1), 39-44. https://doi.org/10.1108/00197850510699965

Martin, C.A., \& Bush, A.J. (2000). Do role models influence teenagers' purchase intentions and behavior? Journal of Consumer Marketing, 17(5), 441-453. https://doi.org/10.1108/07363760010341081

Mitra, S., \& Jenami, M. (2020). OBIM: A computational model to estimate brand image from online consumer review. Journal of Business Research, 114, 213-226. https://doi.org/10.1016/j.jbusres.2020.04.003

Moreno, F.M., Lafuente, J.G., \& Moreno, S.M. (2017). The characterization of the Millennials and their buying behavior. International Journal of Marketing Studies, 9(5), 135-144. https://doi.org/10.5539/ijms.v9n5p135

Motyka, K. (2017). Millennials versus statistics. New Eastern Europe, 6(29), 175-179.

Ng, E.S.W., Schweitzer, L., \& Lyons, S.T. (2010). New generation, great expectations: A field study of the Millennial Generation. Journal of Business and Psychology, 25(2), 281-292. https://doi.org/10.1007/s10869-010-9159-4 
Okyere, N., Agyapong, G., \& Nyarku, K. (2011). The effect of marketing communications on the sales performance of Ghana Telecom. International Journal of Marketing Studies, 3(4), 50-62. https://doi.org/10.5539/ijms.v3n4p50

Ordun, G. (2015). Millennial (Gen Y) consumer behavior, their shopping preferences and perceptual maps associated with brand loyalty. Canadian Social Science, 11(4), 40-55. https://doi.org/10.3968/6697

Pratminingsih, S.A., Astuty, E., \& Mardiansyah, V. (2019). The influence of electronic word of mouth and brand image on buying decision. Journal of Advanced Research in Dynamical and Control Systems, 11(3), 995-1002.

Prensky, M. (2001). Digital natives, digital immigrants. On the Horizon, 9(5), 1-6. https://doi.org/10.1108/10748120110424816

Reicher, R., \& Szeghegyi, Á. (2015). Factors affecting the selection and implementation of a customer relationship management (CRM) process. Acta Polytechnica Hungarica, 12(4), 183-200.

Rimarčík, M. (2007). Štatistika pre prax. Bratislava: Marián Rimarčík.

Shaw, S., \& Fairhurst, D. (2008). Engaging a new generation of graduates. Education Training, 50(5), 366-378. https://doi.org/10.1108/00400910810889057

Solomon, M.R. (1992). Consumer behavior. London, UK: Pearson.

Sung, H.H. (2007). Applying knowledge engineering techniques to customer analysis in the service industry. Advanced Engineering Informatics, 21, 293-301. https://doi.org/10.1016/j.aei.2006.12.001

Swinarski, M.E., Parente, D.H., \& Noce, K. (2010). A study of gender differences with respect to internet socialization of adolescents. Journal of Business \& Economics Research, 8(6), 23-30. https://doi.org/10.19030/jber.v8i6.730

Taylor, C.R. (2018). Generational research and advertising to Millennials. International Journal of Advertising, 37(2), 165-167. https://doi.org/10.1080/02650487.2018.1432102

Valentine, D.B., \& Powers, T.L. (2013). Generation Y values and lifestyle segments. Journal of Consumer Marketing, 30(7), 597-606. https://doi.org/10.1108/JCM-07-2013-0650

Velčovská, Š., \& Hadro, D. (2018). Generation Y perceptions and expectations of food quality labels in the Czech Republic and Poland. Acta Universitatis Agriculturae et Silviculturae Mendelianae Brunensis, 66(1), 325-334. https://doi.org/10.11118/actaun201866010325

Viswanathan, V., \& Jain, V. (2013). A dual-system approach to understanding "Generation Y" decision making. Journal of Consumer Marketing, 30(6), 484-492. https://doi.org/10.1108/JCM-07-20130649

Weingarten, R.M. (2009). Four generations, one workplace: A Gen X-Y staff nurse's view of team building in the emergency department. Journal of Emergency Nursing, 35(1), 27-30. https://doi.org/10.1016/j.jen.2008.02.01

Wong, M., Gardiner, E., Lang, W., \& Coulon, L. (2008). Generational differences in personality and motivation: Do they exist and what are the implications for the workplace? Journal of Managerial Psychology, 23(8), 878-890. https://doi.org/10.1108/02683940810904376

The research paper passed the review process. | Received: April 10, 2020; Revised: June 30, 2020; Accepted: July 16, 2020; Published: December 21, 2020 